Ambiente \& Água - An Interdisciplinary Journal of Applied Science
ISSN 1980-993X - doi:10.4136/1980-993X
www.ambi-agua.net
E-mail: ambi-agua@agro.unitau.br

\title{
Evaluation of coagulation/flocculation process in the landfill leachate treatment at the Municipal Wastewater Treatment Plant
}

\author{
doi: 10.4136/ambi-agua.1187
}

Received: 09 Sep. 2013; Accepted: 22 Oct. 2013

\author{
Juacyara Carbonelli Campos ${ }^{* 1}$; Bruno da Silva Machado; ${ }^{1}$ \\ Maria Emília Drummond Blonski; ${ }^{1}$ Daniele Maia Bila; ${ }^{2}$ \\ João Alberto Ferreira ${ }^{2}$ \\ ${ }^{1}$ Universidade Federal do Rio de Janeiro (UFRJ) - Rio de Janeiro, RJ, Brasil \\ Departamento de Processos Inorgânicos \\ ${ }^{2}$ Universidade do Estado do Rio de Janeiro (UERJ) - Rio de Janeiro, RJ, Brasil \\ Departamento de Engenharia Sanitária e do Meio Ambiente \\ *Autor correspondente: e-mail: juacyara@eq.ufrj.br, \\ brumac53@bol.com.br, mariaemiliablonski@hotmail.com, \\ danielebila@yahoo.com.br,joaf@uerj.br
}

\begin{abstract}
The combined treatment of leachate from urban solid waste landfills in a Municipal Wastewater Treatment Plant (MWTP) minimizes the implementation and operation costs of a landfill. This work investigated the combined treatment of the leachate from Morro do Céu Landfill in Niterói, RJ and sewage samples from Icaraí MWTP with different proportions $(0,0.5,2.0$ and $5.0 \%)$. This MWTP features a physical chemical treatment followed by expulsion through a submarine emissary, and so the physical chemical treatment was simulated. The coagulants used were ferric chloride, aluminum sulfate, Tanfloc SG, Tanfloc SL and Panfloc ${ }^{\mathrm{TM}}$ Hiper Plus in different concentrations (20, 40 and $60 \mathrm{mg} \mathrm{L}^{-1}$ ). During testing, polyelectrolytes in concentrations of 0.5 and $1.0 \mathrm{mg} \mathrm{L}^{-1}$ were added in some samples to stimulate flocculation. The statistical analysis of COD removals showed that Tanfloc SG achieved better results than the other coagulants in all conditions studied, without requiring the addition of polyelectrolytes. Toxicity tests were performed on the raw sewage with a mixture of $5.0 \%$ of landfill leachate and in the mixture treated with Tanfloc SG. The results indicated that the toxicity of the samples is lower than the limit established by current Rio de Janeiro State legislation (NT-213, INEA).
\end{abstract}

Keywords: physical-chemical treatment, sewage, toxicity.

\section{Avaliação do processo de coagulação / floculação no tratamento de lixiviados de aterro sanitário em estação de tratamento de águas residuais}

\section{RESUMO}

O tratamento combinado de lixiviado de aterros de resíduos sólidos urbanos em uma Estação de Tratamento de Esgotos Sanitários (ETE) é um procedimento que tem sido aplicado para minimizar os custos de implementação e operação de um aterro sanitário. Neste trabalho, o tratamento combinado de lixiviado oriundo do Aterro do Morro do Céu, Niterói, RJ, com esgoto doméstico, oriundo da ETE Icaraí, em diferentes proporções $(0,0,5,2,0$ e 5,0 \%) foi 
realizado. Esta ETE apresenta um tratamento físico-químico e posterior lançamento em emissário submarino, dessa maneira o presente trabalho simulou o tratamento físico-químico realizado na ETE. Os coagulantes utilizados foram o cloreto férrico, sulfato de alumínio, Tanfloc SG, Tanfloc SL e Panfloc Hiper Plus ${ }^{\circledR}$ em diferentes concentrações $(20,40$ e $\left.60 \mathrm{mg} \mathrm{L}^{-1}\right)$. Em alguns ensaios, polieletrólitos foram adicionados como auxiliares de floculação, em concentrações de 0,5 e $1,0 \mathrm{mg} \mathrm{L}^{-1}$. A análise estatística de remoções de DQO mostrou que Tanfloc SG obteve os melhores resultados do que os outros coagulantes em todas as condições estudadas, sem necessidade de adição de polieletrólitos. Os testes de toxicidade foram conduzidos com a mistura de 5,0 \% de lixiviado em esgoto bruto e na mistura tratada com Tanfloc SG. Os resultados indicaram que a toxicidade das amostras é inferior ao limite estabelecido pela legislação em vigor no Rio de Janeiro (NT-213, INEA).

Palavras-chave: tratamento físico-químico, esgoto doméstico, toxicidade.

\section{INTRODUCTION}

The industrial and commercial growth in many countries around the world in the past decade has been accompanied by rapid increases in solid waste production. The latest Brazilian National Survey on Basic Sanitation performed by the Brazilian Institute of Geography and Statistics - IBGE, held in 2008 (IBGE, 2010), found that of the 5,562 Brazilian municipalities that practice solid waste management, $50.8 \%$ disposed of the waste at open dumping sites, $21.5 \%$ at controlled landfills and $27.7 \%$ at sanitary landfills.

The "landfill" method for final disposal of urban solid waste uses engineering techniques pre-established rules for planning, construction and operation, thus minimizing risks and environmental problems. The landfill site is carefully selected, planned and prepared. In landfills, the urban solid waste is spread in thin layers, compacted and covered with clay at the end of each operation (Qasim and Chiang, 1994). However, one of the main problems in solid waste management relates to the production and treatment of the landfill leachate.

The National Policy on Solid Waste (PNRS), approved in August 2010, regulates the collection, treatment and final destination of hazardous and industrial wastes, among others. The law establishes important goals for the sector, such as the suspension of open dumping until 2014, the requirement that any part of the waste that cannot be recycled must be sent to a sanitary landfill, and the development and improvement of municipal waste plans.

There is no consensus on the best treatment system for landfill leachate due to variations in its composition. According to Campos et al. (2013), the physical, chemical and biological characteristics of the leachate depend on the type of waste, the degree of waste decomposition, climate, season, landfill age, the depth of the landfill cells and the type of operation of the landfill, among other factors.

The combined treatment of landfill leachate with domestic wastewater in a Municipal Wastewater Treatment Plant (MWTP) has been adopted in many countries as a way to reduce the operational costs of the landfill, where the leachate treatment can be very expensive, especially because it remains necessary even decades after the landfill's closure (Diamadopoulos et al., 1997; Cossu et al., 1998; Ehrig, 1998; Ebert, 1999; Marttinen et al., 2003). The combined treatment can be a viable alternative in Brazilian cities that practice domestic wastewater treatment.

According to Mannarino et al. (2010), combined treatment solves the problems found in treating leachate separately. From the operational perspective of the sewage treatment plants, consideration must be given to the difficulties the leachate might cause in the treatment process, to include an increase in toxicity of the treated effluent.

Icaraí MWTP is located in Niterói City (Rio de Janeiro State), where leachate from Morro do Céu Landfill is mixed with domestic wastewater in a treatment system that features 
primary treatment (coagulation/flocculation) followed by disposal through a submarine emissary.

The current work evaluates the impact of adding different proportions of landfill leachate to sewage in order to simulate a Municipal Wastewater Treatment Plant performing physical chemical treatment (as Icaraí MWTP - RJ State).

\section{MATERIAL AND METHODS}

Domestic wastewater was collected at Icaraí Municipal Wastewater Treatment Plant (MWTP), in Niterói, Rio de Janeiro State. Leachate was collected at the Morro do Céu Landfill, also in Niterói (RJ). The samples were transferred to the laboratory and stored in plastic containers that were kept under $4^{\circ} \mathrm{C}$ until use.

All parameters ( $\mathrm{pH}, \mathrm{COD}$ - Chemical Oxygen Demand, turbidity, ammonia nitrogen, Total Solids -TS and Total Suspended Solids -TSS) were measured based on methodology described in the Standard Method for the Examination of Water and Wastewater (APHA et al., 2005)

This study was performed in three steps. In the first step, mixtures of landfill leachate and raw sewage $(0.5,2.0$ and 5.0\%) were treated with different coagulants and polyelectrolytes. For each coagulant, the minimum concentration that achieved $30 \%$ of COD removal (legal requirement for disposal in a submarine emissary) was chosen. In the second step, these steps were repeated with six different samples of landfill leachate and raw sewage for statistical analysis in order to determine the best coagulant. In the third step, toxicity analyses were performed with 5\% landfill leachate in the sewage mixture (the higher proportion) and in the treated mixture with the best coagulant chosen in the second step.

\subsection{First step: Definition of the optimum condition for each coagulant}

The tests reproduced the actual situation at Icaraí MWTP, where leachate is mixed with domestic wastewater in a treatment system that features primary treatment (coagulation/flocculation) followed by the disposal in a submarine emissary.

The laboratory tests were performed in jar-test equipment (Nova Etica). The methodology was adapted from Jordão and Pessoa (2009) and Castilhos Jr. (2006). The tests conditions were: fast stirring step at $150 \mathrm{rpm}$ ( $2 \mathrm{~min})$; slow stirring at $30 \mathrm{rpm}$ (20 $\mathrm{min})$ and sedimentation for 30 minutes. The parameters evaluated were:

- coagulant: Aluminum sulfate (Vetec), Ferric chloride (Vetec), Tanfloc SG and Tanfloc SL (samples obtained from Tanac Industry) and Panfloc Hiper Plus ${ }^{\mathrm{TM}}$ (sample obtained from Panamericana Industry) were used.

- coagulant concentration: the dosages used were 20, 40 and $60 \mathrm{mg} \mathrm{L}^{-1}$. These values were obtained from literature (Jordão and Pessoa, 2009) and agree with those used at Icaraí MWTP.

- flocculation auxiliary addition: in some tests flocculation auxiliaries were added to determine if this would improve the process. Cationic (FX CS7) and anionic (FX AS6) polyelectrolytes were evaluated, both donated by Faxon Industry. The dosages studied were 0.5 and $1.0 \mathrm{mg} \mathrm{L}^{-1}$.

Sedimentation experiments without chemical additives were also performed. The sedimentation time was 30 minutes.

Table 1 presents the tests performed for each coagulant. All of the experiments were conducted without $\mathrm{pH}$ adjustment. The leachate concentrations in the mixture were $0.5,2$ and $5 \%$, and tests without leachate addition (only raw domestic wastewater) were also conducted.

A minimum COD removal of $30 \%$ was established as the efficiency standard for the experiments. State laws 2,661 and 4,692 (Rio de Janeiro, 1996 and 2005) establish minimum 
levels of domestic wastewater treatment for later disposal through a submarine emissary (30\% removal of BOD - Biochemical Oxygen Demand). Although legislation indicates BOD as the monitoring parameter, COD measurements were done in present work, in order to achieve faster results.

\subsection{Second Step: Determination of the best coagulant}

Six tests of replicas (with different wastewater sampled on different days) in the optimum coagulant condition were conducted during 6 months. The tests were performed for each leachate dilution in domestic wastewater, based on the results of the previous step. The aim of this step was to analyze if the removal rates obtained using different coagulants were equivalent, using statistical data analysis. The best coagulant among the five studied was then determined. The experimental conditions were the same as described in the previous item. Statistical data analysis was also used to determine whether the introduction of landfill leachate in sewage treatment reduces the efficiency of COD removal.

The statistical analyses were done by Minitab 15 software. ANOVA test was used at one factor (One-Way ANOVA), adopting 95\% confidence.

Table 1. Experiments performed at Step 1.

\begin{tabular}{|c|c|c|c|}
\hline \multicolumn{4}{|c|}{ Experiments } \\
\hline \multirow{2}{*}{ Test Code } & \multirow{2}{*}{$\begin{array}{c}\text { Coagulant } \\
\text { Concentration }\left(\mathrm{mg} \mathrm{L}^{-1}\right)\end{array}$} & \multicolumn{2}{|c|}{ Polyelectrolyte } \\
\hline & & Dose $\left(\mathrm{mg} \mathrm{L}^{-1}\right)$ & Type \\
\hline $\mathbf{A}$ & \multirow{5}{*}{20} & - & - \\
\hline B & & \multirow{2}{*}{0.5} & Cationic \\
\hline C & & & Anionic \\
\hline D & & \multirow{2}{*}{1.0} & Cationic \\
\hline $\mathbf{E}$ & & & Anionic \\
\hline $\mathbf{F}$ & \multirow{5}{*}{40} & - & - \\
\hline $\mathbf{G}$ & & \multirow{2}{*}{0.5} & Cationic \\
\hline $\mathbf{H}$ & & & Anionic \\
\hline I & & \multirow{2}{*}{1.0} & Cationic \\
\hline $\mathbf{J}$ & & & Anionic \\
\hline $\mathbf{K}$ & \multirow{5}{*}{60} & - & - \\
\hline $\mathbf{L}$ & & \multirow{2}{*}{0.5} & Cationic \\
\hline $\mathbf{M}$ & & & Anionic \\
\hline $\mathbf{N}$ & & \multirow{2}{*}{1.0} & Cationic \\
\hline $\mathbf{O}$ & & & Anionic \\
\hline
\end{tabular}

\subsection{Third step: Toxicity test}

Toxicity tests were performed to evaluate the toxicity level on live organisms using INEA (Environmental State of Rio de Janeiro Institute) methodology, MF-456. R-0 and ABNT (2004) in order to determine the acute lethal effect of liquid wastewater on the Danio rerio fish species. This test was done with a raw sample (mixture of $5 \%$ of landfill leachate in sewage) and with a corresponding treated sample with the best coagulant selected.

\section{RESULTS AND DISCUSSION}

\subsection{First Step: Definition of the optimum condition for each coagulant}


The samples were collected in monthly intervals, in different periods of the year. The physicochemical parameters characterization results of the leachate and sewage samples are shown in summary in Table 2. Also Table 2 shows COD values for the raw mixtures of leachate in domestic wastewater in the different proportions.

The characterization parameters did not show large variations, except for $\mathrm{N}-\mathrm{NH}_{3}$ and COD.

- Raw sewage

The coagulants $\mathrm{FeCl}_{3}, \mathrm{Al}_{2}\left(\mathrm{SO}_{4}\right)_{3}$, Tanfloc $\mathrm{SL}$ and Panfloc showed the same results, according ANOVA analysis. ANOVA analysis also verified that Tanfloc SG is more efficient than the other coagulants. These results are evident in the Figure 1.

- Mixture $0.5 \%$ (landfill leachate)

ANOVA analysis shows that Tanfloc SL and SG and Panfloc are similar to each other, being more efficient than the ferric chloride and aluminum sulfate. Aluminum sulfate did not show good results even though tested with $1.0 \mathrm{mg} \mathrm{L}^{-1}$ of anionic polyelectrolyte addition.

- $\quad$ Mixture $2.0 \%$ (landfill leachate)

Aluminum sulfate showed the worst performance in this mixture of landfill leachate and sewage, even when $1.0 \mathrm{mg} \mathrm{L}^{-1}$ of anionic polyelectrolyte was added. The other coagulants showed statistically similar results. However, the coagulation using Panfloc included $1.0 \mathrm{mg} \mathrm{L}^{-1}$ of anionic polyelectrolyte.

- Mixture $5.0 \%$ (landfill leachate)

The ANOVA test indicates that the aluminum sulfate results are statistically different from other coagulants. Even though the aluminum sulfate was used with the addition of $1.0 \mathrm{mg} \mathrm{L}^{-1}$ anionic polyelectrolyte, its results were lower than those of other coagulants. The results for the ferric chloride, Tanfloc SG and SL and Panfloc were better than the aluminum sulfate and are equal to each other. It is important to note that the test with Tanfloc SL was performed with the addition of $1.0 \mathrm{mg} \mathrm{L}^{-1}$ of cationic polyelectrolyte. In this work, the polyelectrolyte addition (cationic or anionic) was performed to reach the minimum of $30 \%$ COD removal.

These variations can be explained by weather changes, such as rainfall, since the collection point was the same for all samplings. Mannarino et al. (2010) monitored the Icarai MWTP leachate from Morro do Céu during a year. The authors obtained the following value ranges:

- for raw sewage, $\mathrm{pH}$ : 6.7 - 7.6; Turbidity: 11.0 - $328.4 \mathrm{NTU}$; COD: $53-316$ mg. $\mathrm{L}^{-1}$; TSS: $100-250 \mathrm{mg} . \mathrm{L}^{-1}$ and $\mathrm{N}-\mathrm{NH}_{3}: 11-70 \mathrm{mg} . \mathrm{L}^{-1}$;

- for landfill leachate, $\mathrm{pH}$ : 7.5-8.5; Turbidity: 2.0-70.5 NTU; COD: 685-1913 mg.L ${ }^{-1}$; TSS: $40-473$ mg. $\mathrm{L}^{-1}$ and N-NH$: 522-1394$ mg. $\mathrm{L}^{-1}$.

- Except for the $\mathrm{pH}$ of sewage and landfill leachate, which showed similar value ranges for both studies, the study from Mannarino (2010) shows greater variation than this study, probably because the sampling had been done during a year and so the samples showed a large range of variation.

- Table 3 shows results of COD and Turbidity in the minimum conditions (coagulant and polyelectrolyte dosage) that achieved the minimum removal COD $(30 \%)$. In addition, the results of sedimentation tests without the addition of chemicals did not show removal of COD greater than $30 \%$ (results not shown).

- The results show that, in general, the lowest coagulant concentration produced results higher than $30 \%$ of COD removal. Turbidity results varied, without any specific trend. The COD removal rates tended to decline as the leachate concentration in the mixture increased

The conditions of the second step experiments were based on the results shown in Table 3 
Table 2. Sampling characterization results of landfill leachate, raw sewage and mixtures landfill leachate plus sewage.

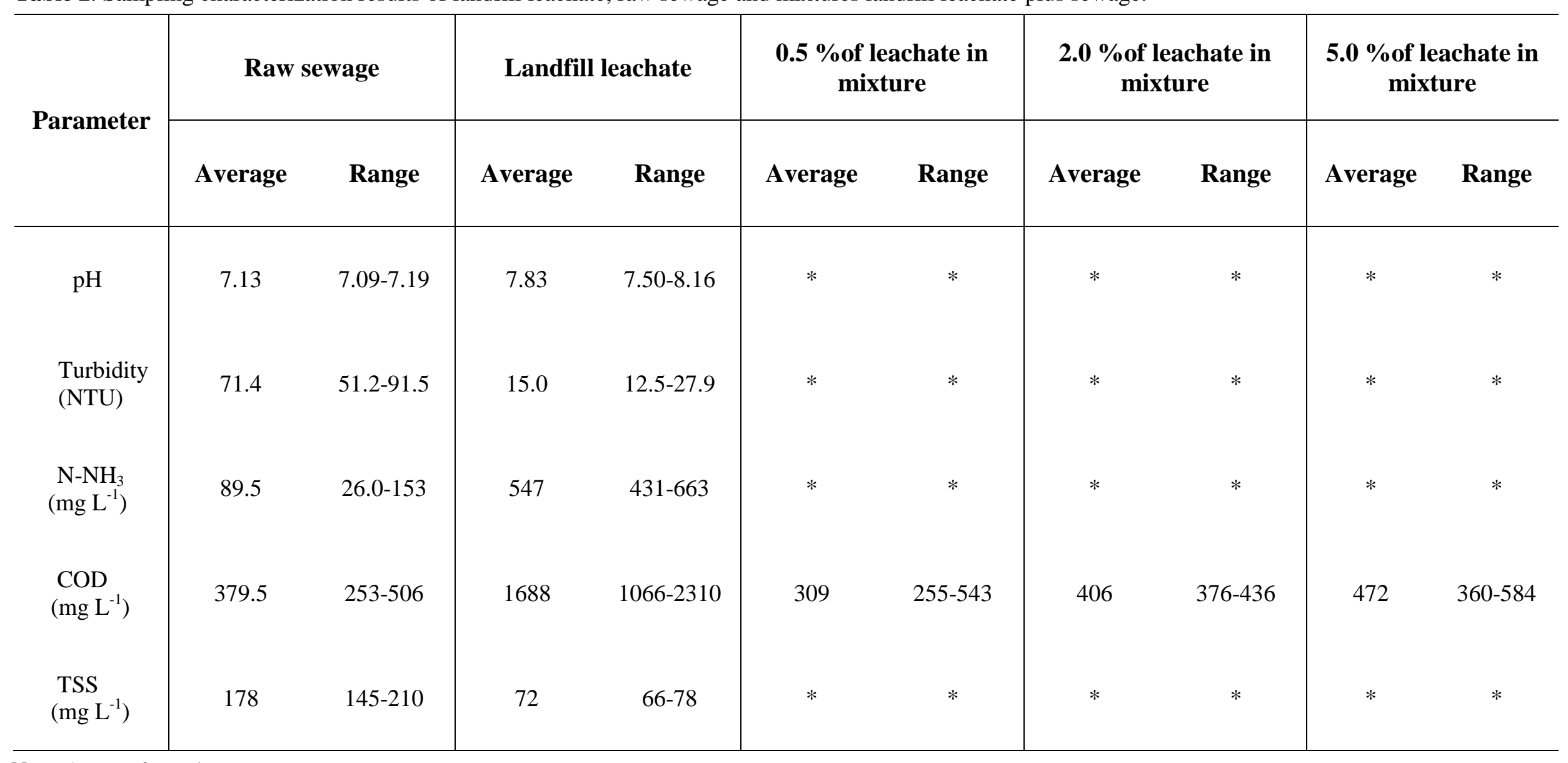

Note: *not performed 
Table 3. COD and Turbidity results for the coagulation/flocculation conditions that achieved the minimum removal COD $(30 \%)$.

\begin{tabular}{|c|c|c|c|c|c|c|}
\hline \multicolumn{7}{|c|}{ RAW SEWAGE } \\
\hline Coagulant & $\begin{array}{l}\text { Concentration } \\
\quad\left(\mathrm{mg} \mathrm{L}^{-1}\right)\end{array}$ & Polyelectrolytes & $\begin{array}{c}\text { Final COD } \\
\left(\mathbf{m g ~ L}^{-1}\right)\end{array}$ & $\begin{array}{c}\text { COD removal } \\
(\%)\end{array}$ & \begin{tabular}{|c|} 
Final \\
Turbidity \\
(NTU)
\end{tabular} & $\begin{array}{l}\text { Turbidity } \\
\text { removal (\%) }\end{array}$ \\
\hline $\begin{array}{l}\text { Aluminum } \\
\text { sulfate }\end{array}$ & 20 & no & 270 & 30 & 63 & 31.4 \\
\hline $\begin{array}{l}\text { Ferric } \\
\text { chloride }\end{array}$ & 20 & no & 152 & 55.6 & 45 & 59 \\
\hline Tanfloc SG & 40 & no & 104 & 50.5 & $*$ & $*$ \\
\hline Tanfloc SL & 20 & no & 145 & 65.1 & 57 & 70.8 \\
\hline Panfloc & 20 & no & 67 & 73.6 & $*$ & $*$ \\
\hline \multicolumn{7}{|c|}{$0.5 \%$ LEACHATE IN THE MIXTURE } \\
\hline $\begin{array}{l}\text { Aluminum } \\
\text { sulfate }\end{array}$ & 60 & $\begin{array}{c}\text { Anionic } \\
0.5 \mathrm{mg} \mathrm{L}^{-1}\end{array}$ & 164 & 39.8 & 22 & 46.2 \\
\hline $\begin{array}{l}\text { Ferric } \\
\text { chloride }\end{array}$ & 20 & no & 278 & 36.1 & 62.4 & 53.5 \\
\hline Tanfloc SG & 20 & no & 94 & 42.9 & * & $*$ \\
\hline Tanfloc SL & 20 & no & 118 & 65.2 & 69 & 78.2 \\
\hline Panfloc & 20 & no & 75 & 70.3 & $*$ & $*$ \\
\hline \multicolumn{7}{|c|}{$2.0 \%$ LEACHATE IN THE MIXTURE } \\
\hline $\begin{array}{l}\text { Aluminum } \\
\text { sulfate }\end{array}$ & 20 & $\begin{array}{l}\text { Anionic } \\
1.0 \mathrm{mg} \mathrm{L}^{-1}\end{array}$ & 151 & 44.5 & 32 & 45.9 \\
\hline $\begin{array}{l}\text { Ferric } \\
\text { chloride }\end{array}$ & 20 & no & 199 & 54.3 & 103 & 23.5 \\
\hline Tanfloc SG & 20 & no & 107 & 35.3 & * & $*$ \\
\hline Tanfloc SL & 20 & no & 195 & 47.3 & 38 & 50.9 \\
\hline Panfloc & 20 & no & 164 & 35.3 & 23 & 47.3 \\
\hline \multicolumn{7}{|c|}{$5.0 \%$ LEACHATE IN THE MIXTURE } \\
\hline $\begin{array}{l}\text { Aluminum } \\
\text { sulfate }\end{array}$ & 20 & $\begin{array}{c}\text { Anionic } \\
0.5 \mathrm{mg} \mathrm{L}^{-1}\end{array}$ & 227 & 37.6 & 43 & 28.3 \\
\hline $\begin{array}{l}\text { Ferric } \\
\text { chloride }\end{array}$ & 20 & no & 237 & 36.3 & 59 & 39.5 \\
\hline Tanfloc SG & 20 & no & 133 & 33.6 & $*$ & $*$ \\
\hline Tanfloc SL & 20 & $\begin{array}{l}\text { Cationic } \\
1.0 \mathrm{mg} \mathrm{L}^{-1}\end{array}$ & 181 & 30 & 31 & 50 \\
\hline Panfloc & 20 & no & 168 & 40.5 & 33 & 27.7 \\
\hline
\end{tabular}

*not performed

\subsection{Second Step: Determination of the best coagulant}

Table 4 shows, in summary, the results achieved at the second step.

Mannarino et al. (2010) also monitored the inflow and outflow of Icaraí MWTP, which during the monitoring period received 0.37 to $1.22 \%$ of landfill leachate. In this period, according to the authors, the treatment efficiency of coagulation/flocculation (chemicals not reported) was on average 55.6\% COD removal. These results are in agreement with those obtained in this work.

The results shown in Table 4 were box plotted using Minitab 15 software (Figure 1).

All of the results were analyzed using ANOVA, fixing a 95\% confidence interval for the test. The results of this analysis are listed below. 
Table 4. Summary of the results of the second step of the work ( $\mathrm{n}=6$ experiments).

\begin{tabular}{|c|c|c|c|c|}
\hline \multicolumn{5}{|c|}{ FERRIC CHLORIDE } \\
\hline \multirow{2}{*}{$\begin{array}{l}\text { Leachate landfill in } \\
\text { the mixture }(\%)\end{array}$} & \multirow{2}{*}{$\begin{array}{c}\text { Coagulant } \\
\text { concentration } \\
\left.(\mathbf{m g ~ L})^{-1}\right)\end{array}$} & \multirow{2}{*}{$\begin{array}{l}\text { Polyelectrolytes } \\
\quad\left(\mathrm{mg} \mathrm{L}^{-1}\right)\end{array}$} & \multicolumn{2}{|c|}{ COD removal $(\%)$} \\
\hline & & & Average Value & Range \\
\hline 0.0 & \multirow{4}{*}{20} & \multirow{4}{*}{ no } & 63 & $55-75$ \\
\hline 0.5 & & & 56 & $48-73$ \\
\hline 2.0 & & & 61 & $53-83$ \\
\hline 5.0 & & & 66 & $52-76$ \\
\hline \multicolumn{5}{|c|}{ PANFLOC } \\
\hline 0.0 & \multirow{4}{*}{$\begin{array}{l}20 \\
20\end{array}$} & \multirow{2}{*}{ - } & 61 & $47-68$ \\
\hline 0.5 & & & 69 & $62-75$ \\
\hline 2.0 & & 1.0 (anionic) & 69 & $56-81$ \\
\hline 5.0 & & - & 68 & $54-76$ \\
\hline \multicolumn{5}{|c|}{ ALUMINUM SULFATE } \\
\hline 0.0 & \multirow[t]{2}{*}{20} & \multirow[t]{2}{*}{ - } & 53 & $52-57$ \\
\hline 0.5 & & & 61 & $58-63$ \\
\hline 2.0 & \multirow[t]{2}{*}{20} & \multirow[t]{2}{*}{1.0 (anionic) } & 55 & $51-60$ \\
\hline 5.0 & & & 50 & $44-60$ \\
\hline \multicolumn{5}{|c|}{ TANFLOC SG } \\
\hline 0.0 & \multirow[t]{2}{*}{40} & \multirow[t]{2}{*}{ no } & 81 & $72-90$ \\
\hline 0.5 & & & 72 & $68-75$ \\
\hline 2.0 & \multirow[t]{2}{*}{20} & \multirow[t]{2}{*}{ no } & 71 & $60-80$ \\
\hline 5.0 & & & 69 & $55-75$ \\
\hline \multicolumn{5}{|c|}{ TANFLOC SL } \\
\hline 0.0 & \multirow{3}{*}{20} & \multirow{3}{*}{ no } & 61 & $46-68$ \\
\hline 0.5 & & & 69 & $62-74$ \\
\hline 2.0 & & & 64 & $58-68$ \\
\hline 5.0 & 20 & 1.0 (cationic) & 69 & $53-76$ \\
\hline
\end{tabular}

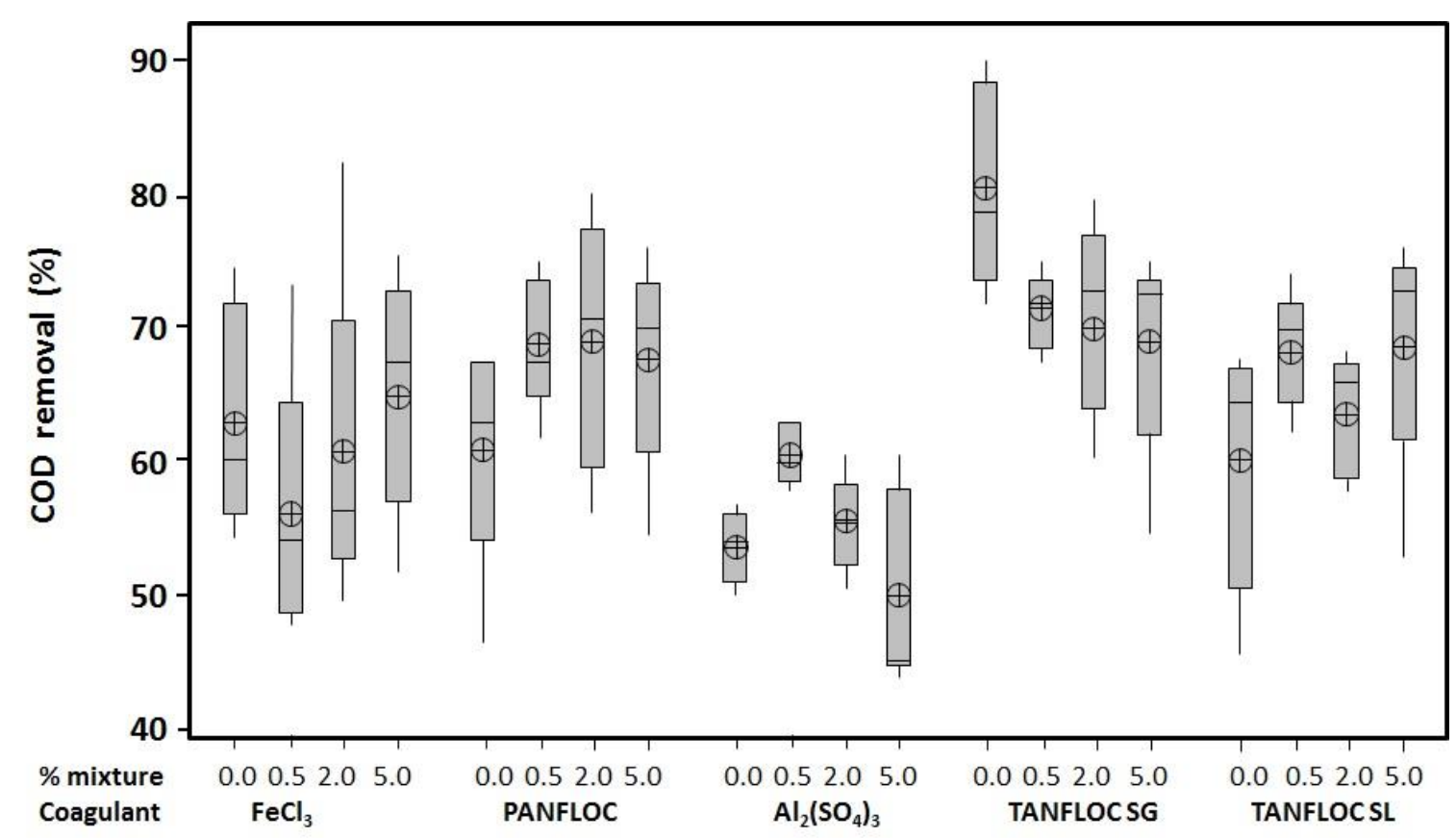

Figure 1. Distribution of COD removal results. 
The results showed that Tanfloc SG is the most efficient coagulant tested in this work, regardless of whether applied to raw sewage or a mixture, because it was the most efficient in all tests without requiring the addition of a polyelectrolyte.

An ANOVA test was applied in order to determine whether COD removals of each coagulant could vary with the leachate concentration in sewage. The results showed that, aside from aluminum sulfate, the addition of landfill leachate did not affect the COD removals, showing that the leachate addition did not impact treatment efficiency.

In case of aluminum sulfate, only the $0.5 \%$ mixture resulted in a statistically significant difference. The results were 58 - $62 \%$ removal of COD for a $0.5 \%$ mixture, while the other mixtures showed removals in the range of $45-55 \%$.

\subsection{Third step: Toxicity test}

According to the Danio rerio toxicity tests, the toxicity factor of the raw sample (5\% mixture) was 4.0 units of toxicity. The same result was obtained for this sample after treatment with Tanfloc SG. These results are below the limit of toxicity for effluents established in current Rio de Janeiro State legislation which is 8 units of toxicity (NT-213, INEA), showing that the coagulant left no toxic residue in the treated effluent.

This result is in agreement with Mannarino et al. (2010) that showed values of 2-4 units of toxicity for 0.37 to $1.22 \%$ of landfill leachate in sewage (the same parameters used in this work).

\section{CONCLUSIONS}

In the present work, laboratory tests were conducted to evaluate the coagulationflocculation process in the treatment of mixtures of domestic sewage and landfill leachate, in order to simulate what happens at Icaraí MWTP. It is important to note that the treatment occurs at the original $\mathrm{pH}$ of the mixture (which is not the optimal coagulation $\mathrm{pH}$ ) and the samples showed significant variations of content during the entire study period. Because of this fact, it was necessary to do statistically analyze the results in order to better evaluate them.

The results show that the primary decantation (without the addition of coagulants) was unable to reach the minimum COD removal of $30 \%$. All of the coagulants effected higher COD removals than the minimum established standard.

Tanfloc SG was found to be the best coagulant and aluminum sulfate the worst. The landfill leachate addition did not affect the results of removal for any of the coagulants, with the exception of aluminum sulfate.

Toxicity tests were performed on the mixture with the highest leachate concentration studied $(5.0 \%)$. The raw sample and the sample treated with Tanfloc SG presented a toxicity factor equal to 4.0 units of toxicity, which is lower than the limit established by current Rio de Janeiro State legislation, i.e., 8.0 unities of toxicity (NT 213 - INEA, 1990).

Based upon this study, it is concluded that the alternative of combining the treatment of leachate in a MWTP configured similarly to Icaraí MWTP (physical chemical treatment and submarine emissary) is viable and results in no degradation of treatment efficiency until a composition of at least $5.0 \%$ landfill leachate.

\section{REFERENCES}

ASSOCIAÇÃO BRASILEIRA DE NORMAS TÉCNICAS - ABNT. Technical Standard NBR

15.088. Aquatic Ecotoxicology - test method with fish. Rio de Janeiro, 2004. 
AMERICAN PUBLICA HEALTH ASSOCIATION - APHA; AMERICAM WATER WORKS ASSOCIATION - AWWA; WATER POLLUTION CONTROL FACILITY - WPCF. Standard methods for examination of water and wastewater. 21th ed. New York, 2005. 1055p.

CAMPOS, J. C.; MOURA, D.; COSTA, A. P.; YOKOYAMA, L.; ARAUJO, F. V. F.; CAMMAROTA, M. C. et al. Evaluation of $\mathrm{pH}$, alkalinity and temperature during air stripping process for ammonia removal from landfill leachate, Journal of Environmental Science and Health, Part A: Toxic/Hazardous Substances and Environmental Engineering, v. 48, n. 9, p. 1105-1113, 2013. http://dx.doi.org/10.1080/10934529.2013.774658

CASTILHOS JR., A. B. (Coord). Gerenciamento de resíduos sólidos urbanos com ênfase na Proteção de corpos d'água: prevenção, geração e tratamento de lixiviados de aterros sanitários. Prosab 4. Petrópolis: Sermograf, 2006. 494p.

COSSU, R.; LAVAGNOLO, M. C.; ANDREOTTOLA, G. Biological removal of nutrients in cotreatment of leachate and sewage. In: INTERNATIONAL TRAINING SEMINAR: MANAGEMENT AND TREATMENT OF MSW LANDFILL LEACHATE, 1998, Venice. Proceedings... Cagliari: CISA, 1998. p. 1-13.

DIAMADOPOULOS, E.; SAMARAS, P.; DABOU, X.; SAKELLAROPOUL, D. P. Combined treatment of landfill leachate and domestic sewage in a sequencing batch reactor. Water Science \& Technology, v. 36, p. 61-68, 1997. http://dx.doi.org/10.1016/S02731223(97)00370-3

EBERT, R. Estudo de regulamentos para recebimento de efluentes não domésticos no sistema público de esgotos. In: CONGRESSO BRASILEIRO DE ENGENHARIA SANITÁRIA E AMBIENTAL, 20., 1999, Rio de Janeiro. Anais... Rio de Janeiro: ABES, 1999.

EHRIG, H. J. Co-treatment in domestic sewage facilities. In: INTERNATIONAL TRAINING SEMINAR: MANAGEMENT AND TREATMENT OF MSW LANDFILL LEACHATE, 1998, Venice. Proceedings... Cagliari: CISA, 1998. p. 1-10.

INSTITUTO BRASILEIRO DE GEOGRAFIA E ESTATÍSTICA - IBGE. Pesquisa nacional de saneamento básico. 2010. Available in http://www.ibge.gov.br/home/ estatistica/populacao/condicaodevida/pnsb2008/PNSB_2008.pdf. Access: 8 Sep. 2013.

INSTITUTO ESTADUAL DO AMBIENTE - INEA. Rio de Janeiro. NT-213, aprovada pela Deliberação CECA n ${ }^{0} 1.948$ de 04 de setembro de1990. Critérios e padrões para controle de toxicidade em efluentes líquidos industriais. Diário Oficial [do] Estado do Rio de Janeiro, Rio de Janeiro, 18 de outubro de 1990.

JORDÃO, E. P.; PESSÔA, C. A. Tratamento de esgotos domésticos. 5. ed. Rio de Janeiro: ABES, 2009. 941p.

MANNARINO, C. F.; FERREIRA, J. A.; MOREIRA, J. C.; BILA, D. M.; MAGALHÃES, D. P. Assessment of combined treatment of landfill urban solid waste leachate and sewage using Danio rerio and Daphnia similis. Bulletin of Environmental Contamination and Toxicology, v. 85, p. 274-278, 2010. http://dx.doi.org /10.1007/s00128-010-0087-9

MARTTINEN, S. K.; KETTUNEN, R. H.; RINTALA, J. A. Occurrence and removal of organic pollutants in sewages and landfill leachates. The Science of the Total Environmental, v. 301, p. 1-12, 2003. http://dx.doi.org/10.1016/S0048-9697(02)00302-9 
QASIM, S.; CHIANG, W. Sanitary landfill leachate. Lancaster: Technomic Publishing Company, 1994.

RIO DE JANEIRO (Estado). Lei n. 2.661, de 27 de dez. de 1996. Regulamenta o disposto no art. 274 (atual 277) da constituição do Estado do Rio de Janeiro no que se refere à exigência de níveis mínimos de tratamento de esgotos sanitários, antes de seu lançamento em corpos d'água e dá outras providências. Available in: <http://alerjln1.alerj.rj.gov.br/ CONTLEI.NSF/c8aa0900025feef6032564ec0060dfff/5a35845b2e69709d032564fb005de9 a4?OpenDocument>. Access in: 8 Sep. 2013. 